\title{
AFINIDADES ELETIVAS E PENSAMENTO ECONÔMICO: 1870-1914
}

João Antônio de Paula

RESUMO $O$ artigo busca mostrar a aplicabilidade do conceito de "afinidades eletivas" para tratar das relações entre o pensamento econômico, a literatura e a filosofia. Em particular destaca-se o pensamento institucionalista, a escola histórica alemã e o pensamento neoclássico.

Palavras-chave Pensamento Econômico, Economia Política Clássica, Economia Neoclássica, Escola Histórica Alemã, Institucionalismo, Afinidades Eletivas

ABSTRACT This article seeks to demonstrate that the concept of "elective affinities" can be applied to the relations between economic thought, literature, and philosophy. The institutionalist thought, the German historical school, and the neoclassical thought are particularly highlighted.

Keywords Economic Thought, Classical Political Economy, Neoclassical Economics, German Historical School, Institutionalism, Elective Affinities

1 Professor da Faculdade de Ciências Econômicas/CEDEPLAR da Universidade Federal de Minas Gerais. Artigo recebido em junho de 2004 e aprovado em junho de 2005. doria @ cedeplar.ufmg.br.

KRITERION, Belo Horizonte, $\mathbf{n}^{\circ}$ 111, Jun/2005, p. 70-90 


\section{Introdução}

Houve quem dissesse, com certa razão, que nós nos parecemos mais com a nossa época do que com nossos pais. Essa idéia, se devidamente desdobrada, permite a aproximação compreensiva de uma problemática — as determinações histórico-materiais do conhecimento - que, por sua complexidade, costuma desconcertar estudiosos e métodos diversos. No centro desses desencontros, que acabaram por resultar em interpretações reducionistas e mecânicas, está a incapacidade de reconhecer a existência de um complexo de mediações, que se interporia entre a realidade histórica e as formas simbólicas da sua representação nos campos da filosofia, da arte e da ciência.

Assim, se é essencial partir da constatação de que as formas de representar o mundo, de algum modo, são determinadas pelo mundo mesmo, é também decisivo que se reconheça que esta relação entre mundo material e mundo simbólico não é direta, linear ou imediata. Isto é, é preciso tomar como dada a intercorrência de turvamentos, de descompassos entre certos momentos — interesses - objetivos, entre certas determinações históricas fortes, decorrentes do monopólio da força ou da legitimidade, e as manifestações concretas dessas intencionalidades sob a forma de símbolos, valores, conceitos.

Há diversas maneiras de buscar entender esses desencontros. Num certo registro haverá quem atribua este efeito à precariedade e nebulosidade da linguagem e, para enfrentar isso, buscará uma linguagem perfeita, uma gramática universal imune à ambigüidade —é o caso da tradição anglo-saxônica da filosofia analítica. De outro lado, haverá quem, recorrendo a Freud, à psicanálise, postule a presença do irredutível a qualquer lógica linear, do inconsciente e dos desejos. Também significativa será a resposta marxista, que invocará, com seus melhores representantes, o inescapável das contradições, a "sombra" produtora de significados que é a alienação, como dimensões essenciais da tensa e complexa relação entre o mundo e suas representações. De tal modo que, no mundo contemporâneo, a partir de diversas matrizes conceituais, já não é possível a crença na existência de uma relação transparente, unívoca, linear e imediata entre a realidade e seus símbolos. Mesmo os métodos quantitativos orgulhosos de seus rigores estatísticos são obrigados a deixar alguma porta aberta para a irrupção do imprevisto.

O texto que se vai ler é uma tentativa de abordar as sutis e complexas determinações histórico-materiais que vão marcar, com sinais nem sempre evidentes, de algum modo, todo um universo simbólico - filosofia, artes, ciência —, com ênfase no pensamento econômico, entre 1870 e 1914.

Esse período, como se sabe, é momento de grandes transformações históricas e culturais, em que o pensamento econômico será, particularmente, 
sacudido pela emergência de grandes correntes e escolas, que marcam, até hoje, o campo de estudos da economia.

Se o período é reconhecidamente importante e tem merecido muitos estudos por parte dos autores que se dedicam à história do pensamento econômico, reivindica-se neste estudo certa originalidade na medida em que se vai buscar entender a questão - as determinações histórico-materiais do conhecimento - a partir da perspectiva abrangente, interdisciplinar e, sobretudo, pelo uso que se vai fazer do conceito de afinidade eletiva, inspirado num texto de Michael Löwy (1989, cap. 1).

\section{O Conceito de Afinidades Eletivas}

A expressão "afinidades eletivas" não está contemplada na Enciclopédia Internacional de Ciências Sociais, também não é verbete do grande Dicionário de Filosofia, de Ferrater Mora. Mais frequiente é encontrá-la nas enciclopédias de ciências naturais e nas de esoterismos. Este fato, é claro, talvez justifique certa estranheza que pode causar ao trazê-la — esta expressão algo misteriosa - para um texto sobre o pensamento econômico.

Foi Santo Alberto Magno, mestre de São Tomás de Aquino, quem no século XIII, utilizou-se da palavra latina affinitas no sentido de "atração, análoga à atração molecular que produz as combinações químicas” (Lalande, 1953, v. I, p. 37). É também de Lalande a crítica:

Afinidades — termo vago que só tem dois empregos mais ou menos definidos: $1^{\circ}$ ) as Afinidades eletivas; título de um romance de Goethe - (Wahlverwandtshaften) era primitivamente uma expressão química devida a Bergmann e que designa as afinidades que destroem um composto em proveito de novas combinações; $2^{\circ}$ ) Afinidade natural das idéias — propriedade que têm os fenômenos psíquicos de atraírem-se um ao outro no campo da consciência por associação de idéias (com semelhanças, ou sem elas). (Lalande, 1953, v. I, p. 37-38).

Neste segundo sentido, Lalande não o diz, mas é forte aqui a insinuação de Freud e seu método de associação de idéias. É também daqui que se pode vislumbrar seu uso por Max Weber. Diz Löwy:

O itinerário desse termo é curioso: vai da alquimia à sociologia, passando pela literatura romanesca. Tem por padrinhos Alberto, o Grande (século XIII), Wolfgang Goethe e Max Weber. Em nossa utilização do conceito, tentamos integrar as diferentes acepções de que a expressão se impregnou ao longo dos séculos. Designamos por "afinidade eletiva" um tipo muito particular de relação dialética que se estabelece entre duas configurações sociais ou culturais não redutível à determinação causal direta ou "influência” no sentido tradicional (Löwy, 1989, p. 13, grifos no original). 
A expressão - afinidade eletiva - parece ter sido usada pela primeira vez em 1775, pelo químico-mineralogista-matemático sueco Torbern Bergmann, em seu livro De attractionibus electivis, traduzido para o alemão com o título Wahlverwanschaft, em 1785, e que será retomado por Goethe em seu romance Wahlverwandtschaften, escrito entre 1808 e 1809 e publicado em 1809.

Nesse romance, Goethe retoma o tema central do seu famoso livro Werther, de 1774, para dar a ele quase um sentido de lei geral. Trata-se do confronto dilacerante que se põe para o herói, Werther, num caso, e Eduardo, no outro, entre o impulso amoroso e a interdição decorrente da moralidade, do decoro que a ética impõe. Entre o imperativo da natureza, que solicita e deseja, e o imperativo moral, que constrange e dignifica, o herói oscila e padece, sem remissão. O amor não se realiza num caso pelo suicídio de Werther, e no outro pela morte de Otília, a amada de Eduardo, atormentada por uma culpa que afinal ela não tem.

Tal é o tom do romantismo alemão: um romantismo que não pode ser explosivo, revolucionário, como na França, que é contido pelas mesmas forças que levaram Kant a falar em "imperativo categórico" - e que é contíguo filosófica e culturalmente do domínio da tradição, da ética, do esteticismo. Diz Rafael Cansinos Assens: "Não há, pois, que temer cataclismos nem catástrofes nesta sólida terra alemã. Número e medida concertam e mantêm a imensidão de seu espaço e a extraordinária atividade, mãos e cérebros. Alemanha é fecunda e prudente (...)" (Cansinos, 1968, t. II, p. 757).

Werther foi publicado em 1774, quando Goethe tinha 25 anos; Afinidades Eletivas, publicada em 1809, é obra de um sexagenário. Muito viveu, amou, estudou o grande homem, e, no entanto, não abandonou a mesma inquietação, a renovada dor pela perda do amor, a chaga aberta do desejo que não tem limites e que se vê interditado pela voz mais alta das convenções, das conveniências, da decrepitude. O jovem e o velho Goethe são sujeitos-objetos de um mesmo e imperioso impulso, uma atração amorosa, que é de tal ordem, que Goethe não hesitará em dar-lhe o lugar de certa universalidade - a afinidade eletiva que, para ele, existe quando dois seres ou elementos "buscamse um ao outro, atraem-se, ligam-se um ao outro e a seguir ressurgem dessa união íntima numa forma (Gestalt) renovada e imprevista" (Goethe apud Löwy, 1989, p. 15).

Da filosofia à química, sem abandonar a alquimia, da química à literatura, e daí à sociologia pela transmutação operada por Max Weber, diz Löwy: 
Da acepção antiga irá conservar as conotações de escolha recíproca, atração e combinação, mas a dimensão da novidade parece desaparecer. O conceito de Wahlverwandtschaft — assim como este outro, de significação próxima: sinnaftinitäten (afinidades de sentido) - aparece em três contextos precisos nos escritos de Weber. Em seu sentido central em Weber o conceito de afinidades eletivas busca "analisar a relação entre doutrinas religiosas e formas de ethos econômico" (Löwy, 1989, p.15).

Muito se escreveu e se discrepou, sobre o sentido real destas relações. Hoje tem certa audiência a tese que reconhece que Weber jamais, e insista-se no termo jamais, estabeleceu qualquer relação de determinação monocausal e direta entre a ética protestante, calvinista, e o capitalismo. De outro lado, vários e significativos autores, como Joseph Gabel e Gabriel Cohn, entre outros, têm mostrado um relativamente amplo espectro de convergência e complementariedades, sem que isso signifique apagamento de diferenças, entre Marx e Weber (Gabel, 1973; Cohn, 1979).

Mas não é esta a questão que se quer sublinhar aqui. O que importa destacar é o quanto o conceito de afinidade eletiva abre possibilidades para a compreensão de realidades complexas, de relações complexas pela superação do "reducionismo correlacionista", desculpe-se o neologismo, que é típico do dominante nos métodos quantitativos e suas aplicações em ciências sociais. Veja-se o trecho a seguir:

Não é estranho que essa expressão não tenha sido compreendida na recepção anglosaxônica positivista de Max Weber. Um exemplo quase caricatural é a tradução inglesa da Ética Protestante por Talcott Parsons (em 1930): Wahlverwandtschaft exprime-se (...) ora por certain correlations, ora por those relationships. Enquanto o conceito weberiano remete a uma relação interna, rica e significativa entre as duas configurações, a "tradução-traição" de Parsons o substitui por uma banal relação (ou correlação) exterior e vazia de sentido. Nada poderia ilustrar melhor que tal conceito é inseparável de um certo contexto cultural, de uma tradição que lhe confere toda a força expressiva e analítica. (Löwy, 1989, p. 15-16, grifos no original)

Ou seja, tanto a produção quanto a recepção, quanto a apropriação dos conceitos, inclusive do próprio conceito de afinidade eletiva, têm sido sempre o resultado de uma complexa trama de aproximações e repulsões, de afinidades e interditos, de movimentos de convergência, de atração recíproca, de combinação, podendo chegar à fusão (Ibidem, p. 18), em múltiplas escalas e temporalidades. Para Löwy, é o conceito de afinidades eletivas que permite entender os laços invisíveis e poderosos que unem:

1. a ética cavaleiresca e a doutrina da Igreja;

2. a cabala e a alquimia; 
3. o conservantismo tradicionalista e o romantismo;

4. o darwinismo e o malthusianismo;

5. a moral kantiana e a epistemologia positivista;

6. a psicanálise e o marxismo;

7. o surrealismo e o anarquismo.

E diga-se, para concluir e colocar a questão nos seus termos, que a afinidade eletiva, no sentido em que estrutura os pares anteriores, não é afinidade ideológica; não é correlação; nem é influência. (Löwy, 1989).

Max Weber disse que os determinantes do processo de racionalização do Ocidente devem ter um fundamento antropológico:

Quando nos deparamos repetidamente, com o fato de que no Ocidente, e só no Ocidente, e em âmbitos da vida aparentemente independentes uns dos outros desenvolvem-se determinados tipos de racionalização, parece natural supor que as características hereditárias constituam seu substrato decisivo. (Weber, 1992, v. I p. 24)

Contudo, segundo ele, a pesquisa antropológica não havia avançado o suficiente para contribuir para a elucidação da questão. De tal modo que, na verdade, continua, ainda hoje, por se responder inteira e satisfatoriamente ao seguinte: "qual encadeamento de circunstâncias levou a que aparecessem no Ocidente, e só no Ocidente, fenômenos culturais que (ao menos tal como tendemos a representá-los) se inserem em uma direção evolutiva de alcance e validade universais?" (Ibidem, p. 11).

A resposta que vai se intentar aqui, partindo do desafio de Weber, reconhecendo a contribuição de sua proposta de reafirmação do conceito de afinidade eletiva como contraponto saudável e necessário à epistemologia positivista, nega esse mesmo ponto de partida weberiano na medida em que este se estreita e se apequena como no que se refere ao uso do conceito de "Ocidente" tomado em uma pura dimensão espacial. Limitar o conceito de Ocidente à sua expressão geográfica é desconsiderar o quanto as culturascivilizações não ocidentais foram decisivas na constituição da cultura helênica, é desconsiderar o papel essencial da cultura-civilização islâmica na preservaçãodesenvolvimento da cultura-civilização helênica e helenística, bases decisivas da modernidade ocidental.

Nesse sentido, o reparo a se fazer a Weber é quanto ao fato de ele não ter extraído todas as conseqüências necessárias do conceito de afinidade eletiva, que é, sobretudo, um conceito dialético. Isto é, um conceito que se realiza pela interveniência da mediação, da interação, da fusão, da metamorfose. Disse Löwy: 
É um conceito que nos permite justificar processos de interação que não dependem nem da causalidade direta, nem da relação "expressiva" entre forma e conteúdo (por exemplo, a forma religiosa como "expressão" de um conteúdo político ou social). (...) Naturalmente, a afinidade eletiva não se dá no vazio ou na placidez da espiritualidade pura: ela é favorecida (ou desfavorecida) por condições históricas ou sociais. (...). Neste sentido, uma análise em termos de afinidade eletiva é perfeitamente compatível com o reconhecimento do papel determinante das condições econômicas e sociais. (Löwy, 1989, p. 18).

\section{As Determinações Históricas do Pensamento Econômico}

A história do pensamento econômico tem sido a história de certas controvérsias. Algumas delas são tão antigas quanto a própria emergência da problemática que vai identificar o campo de conhecimento da economia na modernidade. É o caso, por exemplo, do referente a teoria do valor. Diz Foucault:

(...) a economia apenas conhece um único segmento teórico, mas que é sustentável simultaneamente de duas leituras feitas em sentido contrário. Uma análise do valor a partir da troca de objetos de necessidade, objetos úteis; a outra a partir da formação e do nascimento dos objetos, cuja permuta definirá em seguida o valor (...). Entre estas duas leituras possíveis, um ponto de heresia que nos é familiar, o qual separa o que se denomina "teoria psicológica" de Condillac, de Galiani, de Graslin, da teoria dos fisiocratas, com Quesnay e a sua escola (Foucault, [s.d.], p. 255, grifos no original).

Uma outra dicotomia, que também vinca o pensamento econômico, desde o seu nascimento na modernidade, é a que perfila de um lado os adeptos de uma visão que atribui ao mercado, ao reino do interesse individual livremente exercitável, virtudes regulatórias inexcedíveis ao mesmo tempo que propiciadoras de prosperidade econômica; de outro lado, os que entendem a intervenção do Estado como instrumento necessário para a garantia do funcionamento da economia, a qual, entregue aos apetites dos agentes individuais, estaria permanentemente sujeita às crises e à disrupção.

Em todo caso, vale a pena começar por reconhecer que não há coerência estreita, em qualquer sentido, no interior dessas correntes, sendo incontáveis as situações híbridas, como a que é representada por Marshall que buscou fundir as teorias subjetiva e objetiva do valor, mediante o conceito de custo real subjetivo, e a igualmente híbrida reivindicação dos socialistas fabianos, que, adeptos de uma perspectiva de socialização mediante a ação de um Estado de Bem-Estar Social, fundam suas teses na teoria neoclássica do valor.

De resto, é fundamental reconhecer que, ainda que assemelhadas em aspectos estruturais - por exemplo, as teorias identificadas com a chamada 
revolução marginalista —, distinguem-se, significativamente, pela manifestação de "características nacionais", de "estilos nacionais de pensamento", determinando, ao mesmo tempo, semelhanças e diferenças que marcam as obras de Jevons, Menger e Walras.

Busca-se neste texto discutir as condições da produção do conhecimento no campo do pensamento econômico no período que vai de 1870 a 1914 . Isto é, na periodização de Hobsbawm, a era dos impérios. É sobre essa época que este artigo se debruça. Contudo, para a clareza do argumento, é necessário certo recuo no tempo para contemplar dois outros períodos da tematização de Hobsbawm - a era das revoluções, de 1789 a 1848; e a era do capital, de 1848 a 1875 .

Cada uma dessas épocas é tomada por Hobsbawm a partir da centralidade da luta de classes, que impacta tanto a construção da hegemonia econômicopolítica quanto a construção das hegemonias simbólicas. Nesse sentido, o período que vai de 1789 a 1848 é a época da vitória da revolução burguesa em vários sentidos. No campo especificamente econômico-material, é o momento da consolidação da Revolução Industrial britânica, da consolidação do modo de produção especificamente capitalista. No que se refere às instituições políticas, é o momento da constituição do Estado burguês por antonomásia com a Revolução Francesa. No plano filosófico, a obra de Hegel é o equivalente, no plano das idéias, da celebração da ousadia da burguesia que, em um "assalto aos céus", não hesita em reivindicar-se sujeito da emancipação humana. No campo artístico, o Romantismo é o desafio altivo a todas as convenções formais.

Não se veja no período apenas o revolucionário, pois a época também foi de reação, et pour cause. E, assim, a França, que desconstruiu, radicalmente, o Antigo Regime, também o recriou, com a restauração de 1815 e com as obras De Bonald (1759-1840) e De Maistre (1753-1821).

Mas, a curta restauração bourbônica, 1815-1830, não impediu a imposição de uma tendência geral, que é a da revolução, e que se surpreende, de algum modo, na obra de aristocratas, que, tendo sido, em algum momento, realistas e católicos conservadores, como Chateaubriand (1768-1848), Lamartine (17901869), Lamennais (1782-1854), Benjamin Constant (1767-1830), viveram tensões ideológicas agudas. Como viu Carpeaux, "a atitude ambígua a respeito de Napoleão e das instituições monárquicas, o liberalismo moderado, as angústias religiosas sobre o fundo de uma irreligiosidade irremediável (...)" (Carpeaux, 1962, v. IV, p. 1684).

A era das revoluções, 1789-1848, começa com a grande Revolução Francesa e termina com o ciclo de revoluções de 1848-1849, que vai sacudir 
quase toda a Europa. Se em alguns países, como a Alemanha, a revolução terá o sentido da reivindicação democrático-nacional, em outros, como na França, a revolução assume o sentido de uma despedida — a despedida da burguesia de seu momento progressista —, é a vitória do conservantismo, vitória feita de violência contra os trabalhadores, "o pecado original da burguesia francesa", como disse Sartre, que abriu caminho para a consolidação, em todas as linhas, dos interesses do capital.

Um campo em que esta problemática é, particularmente, expressiva é o da economia política. No centro da questão está a "reação contra Ricardo", como disse Maurice Dobb, a partir dos anos 1830, e que Marx vai chamar de emergência da "economia vulgar". Trata-se do processo da contestação e abandono da rica tradição, que, iniciada no século XVII, com Petty, teve seus momentos superiores com Adam Smith e David Ricardo. Em 1831, no Political Economy $C l u b$, Robert Torrens vai dizer: “(...) todos os grandes princípios da obra de Ricardo foram sucessivamente abandonados e suas teorias do valor, da renda e do lucro, no que têm de geral, foram tidas, agora, como errôneas". (Torrens apud Dobb, 1975, p. 111). Nesse sentido, a defesa de Ricardo, feita por John Stuart Mill em seu Principles, de 1848, é quase um ato de desagravo inócuo num momento em que a economia política clássica, com o próprio livro de Stuart Mil, se despede, incapaz de balizar o pensamento econômico que se desenvolvia então.

Marx vai considerar a questão em seu livro Teorias sobre a Mais Valia, escrito entre 1862 e 1863 e publicado, por Kautsky, entre 1905 e 1910. Ali, depois de elogiar a grande tradição da economia política clássica, Marx vai reconhecer a presença de uma contradição, que resulta na própria conclusãorealização de seu papel histórico. Para ele, este é um complexo e sutil processo de "autonomização" e "exteriorização" de certos elementos vulgares, que, contidos, mesmo na obra de Smith e Ricardo, foram apropriados pela economia vulgar de forma a transformá-los de secundários e contingentes em principais e determinantes. Diz Marx:

Com Ricardo e o desenvolvimento posterior da economia baseada nele, adquire o economista vulgar novo alimento (posto que não produz nada de novo por sua conta), e quanto mais vai aproximando-se a economia do seu fim, isto é, quando aprofunda e desenvolve-se como sistema de contradições mais independência assume frente a ela seu elemento vulgar, mais se enriquece este com matéria que elabora a seu modo, até que, por último, encontra sua expressão mais acabada como uma compilação eruditasincrética-eclética e carente de qualquer "caráter" (Marx, 1980, v. III, p. 443-444, grifos meus). 
Para Marx, esse é um processo cumulativo, sintonizado ao ritmo geral da luta de classes - "(...) a evolução da economia política e da reação que ela mesma engendra (contra si mesma) se acha em consonância com o desenvolvimento real dos antagonismos sociais e das lutas de classes inerentes à produção capitalista" (Marx, 1980, v.III, p. 443, grifo no original).

Assim, houve um tempo em que Say, que é, talvez, o pai da economia vulgar, pôde aparecer a Marx como "economista crítico e imparcial - porque encontrou as contradições relativamente pouco desenvolvidas em A. Smith se o compararmos, por exemplo, com Bastiat, o harmonicista e apologista profissional (...)" (Ibidem, p. 444).

Trata-se, no essencial, de apreender nessa era das revoluções a existência de dois núcleos, independentes, de contradições — um que decorre do próprio desenvolvimento histórico, que terá momento de auge nas Revoluções de 18481849; e outro que é o resultado do rebatimento dessas contradições sobre o plano especificamente simbólico, plano este que, de nenhum modo, deve ser visto apenas como realidade refluxa, determinada exclusivamente pelas vicissitudes da luta de classes.

De qualquer modo, as Revoluções de 1848-1849 vão determinar na Europa um novo tempo. Enfraquecido, o movimento operário e socialista viverá refluxo. O espectro que rondou a Europa parecia conjurado, e a burguesia pôde lançarse aos grandes investimentos ferroviários que, definitivamente, consolidarão a Revolução Industrial.

É a era do capital (1848-1875), disse Hobsbawm. Seus momentos marcantes são, no plano simbólico, a inauguração do Palácio do Cristal, em Londres, em 1851, e as reformas urbanas conduzidas pelo barão de Haussmann, em Paris, na década de 1860. No plano político, seus maiores triunfos são a vitória do Norte na guerra civil norte-americana (1861-1865) e a unificação nacional da Itália e da Alemanha entre 1861 e 1870.

Já no final do período em tela - 1848/1875, dois eventos expressivos vão redefinir o quadro sócio-econômico-político-cultural: a Comuna de Paris, em 1871, que é a demonstração, trágica e heróica da consolidação da força dos trabalhadores e da ideologia socialista entre eles; e a Grande Depressão, que se inicia em 1873 e significa a explicitação da crise do modo de acumulação de capital típico da Revolução Industrial desenvolvida a partir da Grã-Bretanha.

Tanto a Comuna de Paris quanto a Grande Depressão são indícios de transformações importantes que ocorriam tanto no plano político-cultural, quanto no modo de funcionamento da economia capitalista. Na verdade, não será exagero de anacronismo se se disser que é a forma como esses eventos- 
desafios foram enfrentados que definirá a fisionomia do novo tempo que se abria — a era dos impérios: 1875-1914.

Restrinja-se a discussão ao específico do pensamento econômico. A era dos impérios, do ponto de vista do pensamento econômico, será o tempo: da consolidação da revolução marginalista; do marxismo; da eclosão da chamada nova escola histórica alemã, liderada por Schmoller; da emergência da economia institucionalista. Esta profusão de teorias está longe de ser trivial e exige, desde logo, que se reconheça o período como momento especial tanto da história das idéias, quanto da história em geral.

$\mathrm{E}$, aqui, retome-se o conceito de afinidade eletiva. A física newtoniana estabeleceu um tal justo fascínio que atraiu parte considerável do pensamento ocidental do século XVIII. Influência decisiva, atração irresistível de largo espectro. São de Newton, são de sua física os fundamentos do projeto crítico de Kant. É também de Newton a referência estrutural, o modelo-metáfora, tanto para a economia política de Adam Smith, quanto para a economia pura de Walras, no século XIX. No caso de Walras, ele registra o quanto foi decisivo para a sua teoria a obra de Louis Poinsot e seu manual newtoniano de mecânica estática (Paula, 2002). E, no entanto, eram muito distintos os ambientes e motivações da Grã-Bretanha de Smith (1723-1790) e da França/Suíça de Walras (1834-1910): a Grã-Bretanha, no curso de sua Revolução Industrial, e a França, já vivendo as conseqüências da contestação socialista à dominação burguesa. Entre os dois momentos, as duas culturas, os dois personagens, tece-se o laço da afinidade eletiva que é a dominância de certa perspectiva que Koyré viu assim:

Ao fim do século, o triunfo de Newton era completo. O Deus newtoniano reinava, supremo, infinito do espaço absoluto, no qual a força da atração universal interligava os corpos estruturados atomisticamente no universo incomensurável e os fazia moverem-se de acordo com rígidas leis matemáticas. (Koyré, 1979, p. 255).

Este universo de corpos isolados, interligados por força de atração universal, será a metáfora-modelo básica tanto da física, quanto das economias clássica e neoclássica, da sociologia, de Comte, no século XIX: afinidades eletivas que são a expressão, no campo simbólico, da dominância do individualismo, do liberalismo no campo das relações econômico-políticas, das instituições sociais, contra o Antigo Regime e a velha metafísica, tanto no caso de Newton, Kant e Adam Smith, como no caso de Comte e Walras.

Há um fundo de anacronismo e explícito comprometimento ideológico no projeto das correntes neoclássicas, que surgem, simultânea e independentemente, na Inglaterra, na Áustria e na França, entre 1871 e 1874. 
Afinal, continuar a pensar a economia como Ersatz de um "universo composto de corpos isolados regidos por uma força de atração universal", o interesse individual tomado como princípio movente e constituinte das relações econômicas, é, na verdade, uma petição de princípio em tudo distante do concreto das ações de Estados, empresas e indivíduos, como o comprova o insuspeito exemplo dos Estados Unidos e a ação protecionista-intervencionista de Alexander Hamilton.

A segunda metade do século XIX será marcada: pelas industrializações comandadas pela ação combinada de bancos e Estados, como mostrou Gerschenkron (1968); pela consolidação de monopólios, oligopólios e imperialismos; pelo avanço do movimento socialista e da ação sindical; pela emergência do Estado de Bem-Estar Social, condições histórico-materiais e culturais, que ensejarão-alimentarão outras afinidades eletivas. É o momento em que vão eclodir, como contestações, parciais ou globais, ao paradigma clássico-neoclássico em economia, tanto o marxismo, quanto a nova escola histórica alemã, bem como a economia institucionalista.

\section{Atrações Irresistíveis e Insuspeitadas}

Explicitamente, quase sempre, tanto a escola histórica alemã, quanto a economia institucionalista são esforços críticos à tradição da economia clássica e neoclássica. Contudo, estará em erro quem pressupuser que há relações de determinação lineares, unívocas entre contextos históricos e formas simbólicas típicas e necessárias destes contextos. Se a escola histórica alemã tem história que se confunde com as peculiaridades do desenvolvimento industrial alemão, seu caráter retardatário e fortemente apoiado na intervenção estatal, a mais característica corrente norte-americana de pensamento econômico é o institucionalismo, o que é, de certo modo, desconcertante na medida em que ele é, sob certos aspectos, uma crítica veemente ao exuberante individualismo hedonista e privatista, que é quase sinônimo do ethos dominante naquele país.

O quadro fica ainda mais complexo se se lembrar que é na Alemanha, com Hermann Heirinch Gossen, em 1854, que surge a obra verdadeiramente inauguradora da perspectiva neoclássica, que vai se consolidar entre 1871 e 1874. Diz Eric Roll: “Assim, o livro de Gossen contém os elementos principais da teoria de Jevons e da austríaca. Nele se mostra o aparelhamento geométrico e algébrico. Mas as condições de seu tempo não estavam ainda preparadas para que se fizesse tão decidido uso do método subjetivo." (Roll, 1972, p. 374). Também atesta a ausência de determinismos fáceis o reconhecimento do quanto os Estados Unidos, se viram nascer o institucionalismo, foram pródigos 
também no desenvolvimento da ortodoxia neoclássica. Dizem Screpanti e Zamagni:

\begin{abstract}
Nos anos 1890 a economia clássica quase havia desaparecido completamente da cena. Ao mesmo tempo, nesta mesma década têm início os ataques à economia política que tornaram-se também censuras à economia neoclássica. E isto aconteceu nos Estados Unidos com a escola institucionalista. Esta linha de pensamento foi iniciada por Veblen nos anos 1890 e desenvolvida por muitas gerações de institucionalistas nas décadas seguintes. Nos Estados Unidos, estes desenvolvimentos e suas críticas foram sempre acompanhados (talvez decorrente do fraco desenvolvimento da crítica marxista) do desenvolvimento da ortodoxia neoclássica. (Screpanti e Zamagni, 1993, p. 280)
\end{abstract}

Ou seja, a Alemanha campeã de resistência à tradição clássica e neoclássica, é o locus da pioneira emergência da teoria neoclássica, ao passo que os Estados Unidos, espaço da mais entusiástica recepção da teoria neoclássica, também produziram o institucionalismo que, sob vários aspectos, é um questionamento de fundo à tradição neoclássica.

De outra natureza é a crítica de Marx ao pensamento clássico. Marx, explicitamente, coloca-se num outro lugar, o lugar da "superação", no sentido hegeliano, no referente à tradição clássica, em economia. Ao que fez, sua obra no campo da economia, deu o nome de crítica da economia política, e, com isso, ele queria dizer que tanto a problemática quanto as categorias e métodos utilizados em sua abordagem de questões econômicas não são a simples reposição do pensamento clássico. Reconhecendo os méritos desta escola, Marx não só deu respostas diferentes às questões decorrentes do pensamento clássico, mas também "inventou" questões novas, como, por exemplo, a referente à forma do valor (Rubin, 1974).

Nesse sentido, a trajetória crítica de Marx distingue-se radicalmente da crítica dos historicistas e dos institucionalistas. É que para Marx, na verdade, o que está em questão, no referente ao pensamento clássico, não é o eventual equívoco conceitual, a incorreção factual, a falha lógica. Sobre isso é significativo que Marx tenha, em certo momento, partilhado das mesmas desconfianças que a escola histórica alemã em relação à teoria do valor. Ernest Mandel mostrou que, até a elaboração do livro A miséria da Filosofia, em 1847, Marx criticou a teoria ricardiana do valor de um ponto de vista semelhante ao dos historicistas (Mandel, 1968, cap. 3). Mais tarde ele vai aceitar a teoria ricardiana e, num momento, seguinte vai superá-la, numa operação em que, ao mesmo tempo, conservam-se certos elementos da teoria do valor-trabalho e rejeitam-se outros, realizando uma síntese original de toda a tradição da teoria do valor trabalho. Isso distingue Marx dos historicistas em um aspecto essencial: a crítica de Marx aos clássicos não é uma crítica por interdição-rejeição externa, 
como a dos historicistas, mas uma crítica que, tendo mergulhado no material da teoria do valor, atravessa-o, supera-o, pelo estabelecimento de seus limites. Do mesmo modo, quando comparado com o pensamento institucionalista, ressalta-se a diferença de amplitude e profundidade da crítica marxista ao pensamento clássico-neoclássico. A. Gruchy, citado por Screpanti e Zamagni, diz dos autores institucionalistas: "[eles] se ocupam de problemas tais como impacto da mudança tecnológica sobre a estrutura e funcionamento do sistema econômico, as relações de poder entre grupos de interesses, a lógica do processo da industrialização e a determinação das noções de metas e prioridades". (Gruchy apud Screpanti e Zamagni, 1993, p. 281).

Não há dúvida de que estas são questões importantes e representam avanços em relação à tradição neoclássica. Contudo, do ponto de vista da teoria marxista, estes avanços têm um limite decisivo. $\mathrm{Na}$ verdade, o que o marxismo diria sobre este elenco de questões relevantes é que ele só pode ser efetivamente compreendido quando considerado no quadro geral das relações econômicosociais e, mais decisivo, quando cada uma das questões de que é composto for considerada em suas determinações histórico-materiais. Isto é, quando se buscar entender a produção social destes eventos-questões, de tal maneira que, para o marxismo, a própria "agenda" institucionalista só possa ser enfrentada, teoricamente, quando ela própria for entendida como "problema", sob pena de, não sendo considerada em suas conexões histórico-sociais, resultar num conjunto arbitrário.

Mas não é uma comparação entre teorias, avaliação de méritos e limites que se quer fazer aqui. O objetivo desta parte do trabalho é apontar para insuspeitadas afinidades eletivas entre pensamento econômico e certas manifestações culturais do final do século XIX e início do XX. Como advertência inicial reconheça-se: que não é possível, nem desejável, estabelecerem-se relações diretas e imediatas entre a história concreta e as formas simbólicas que suscita e acolhe, nem destas entre si de maneira igualmente direta e imediata, ainda que estas relações existam e sejam determinantes de algum modo.

O que se quer dizer é que há afinidades eletivas entre certas correntes artístico-filosóficas e correntes do pensamento econômico. Assim, não será forçar a mão reconhecer o parentesco espiritual entre empirismo, racionalismo, Iluminismo, Classicismo, Realismo, Naturalismo, Positivismo e pensamento econômico clássico e neoclássico. Do mesmo modo, não será artificial ver contigüidade entre o Romantismo filosófico-literário - Herder, Fichte, Novalis, Goethe - e a escola histórica alemã em suas três etapas: a velha escola, com Roscher, na década de 1840; a nova escola na década de 
1880, com Schmoller; e a novíssima, no início do século XX, com Werner Sombart e Max Weber.

Quanto ao institucionalismo, é possível vê-lo como contraponto, no campo do pensamento econômico, ao que nas artes plásticas, na literatura, na música, mas também na física, foi representado pelo Simbolismo, pelo Impressionismo, pela física quântica e pela física probabilística. Isto é, a busca da representação do mundo mediante as percepções cambiantes da cor, da luz, do tempo, das sensações: o mundo de Monet, de Manet, de Bergson, de Debussy, de Mahler, de Mallarmé, de Rimbaud, de Verlaine, de Valéry, de Proust, de Joyce, de Planck, de Boltzmann; mundo em que a pretensão monológica do determinismo estreito é mitigada pelo reconhecimento da indeterminação, do acaso, da incerteza.

Não será equívoco apresentar o pensamento institucionalista como se segue: o tema, objeto central da economia seria o comportamento, de indivíduos e instituições, tomados como partes de um todo orgânico e dinâmico, cuja matriz referencial básica é, ao contrário da metáfora newtoniana presente no pensamento clássico-neoclássico, a teoria evolucionista. Veja-se o trecho:

O institucionalismo e o behaviorismo, estreitamente relacionado com aquele, partiam do suposto de que os atos econômicos são governados não só pelo princípio hedonístico. O comportamento econômico do homem, seus desejos, necessidades, sua forma de atuar e seus meios são simples funções de uma evolução constantemente cambinante, infinitamente complexa, moldada por instituições sociais concretas e, neste sentido, "institucionais". (Surányi-Unger, 1975, v. 7, p. 751).

O grande nome do pensamento institucionalista, seu criador, é Thorstein Veblen (1857-1929). Erudito pensador norte-americano, Veblen estudou ciências naturais, filologia, filosofia e economia. Sua obra repercute influências e afinidades com o pragmatismo norte-americano (Dewey, William James e Peirce), com o evolucionismo, (à moda de Darwin e Spencer). Sua obra, que possui certo vezo etnológico - a etnologia da burguesia norte-americana -, tem, a rigor, três grandes campos de reflexão, articulados por pares conceituais dicotômicos. No referente à psicologia, a estrutura do argumento de Veblen se dá pela dicotomia entre "instinto predatório-destrutivo X instinto construtivo". No campo sociológico, a dicotomia é entre os conceitos de "classe ociosaconsumo conspícuo X homem comum-trabalhador". No mundo da economia, a dicotomia é entre "negócio X indústria". Estes conceitos, e seus desdobramentos, foram formulados em dois livros decisivos de Veblen $-A$ teoria da classe ociosa, de 1899, e Teoria da empresa industrial, de 1904.

Um quadro das estruturas conceituais de Veblen evoca temas freudianos, em particular, a dicotomia Eros X Thânatos. Veja-se o quadro: 


\begin{tabular}{|l|l|l|}
\hline & Instituto predatório/destrutivo & Instituto Construtivo \\
\hline Psicologia & $\begin{array}{l}\text { Destruição } \\
\text { Dominação } \\
\text { Exploração } \\
\text { Agressividade }\end{array}$ & $\begin{array}{l}\text { Instinto grupal } \\
\text { Curiosidade desinteressada } \\
\text { Criatividade afetiva }\end{array}$ \\
\hline Sociologia & $\begin{array}{l}\text { Classe ociosa } \\
\text { Banqueiros/corretores } \\
\text { Advogados/burocratas } \\
\text { Emulação pecuniária } \\
\text { Ócio conspícuo } \\
\text { Consumo conspícuo } \\
\text { Lazer conspícuo }\end{array}$ & $\begin{array}{l}\text { Engenheiros } \\
\text { Técnicos } \\
\text { Trabalhadores }\end{array}$ \\
\hline \multirow{5}{*}{ Economia } & $\begin{array}{l}\text { Negócio } \\
\text { Aquisição } \\
\text { Lucro }\end{array}$ & $\begin{array}{l}\text { Propriedade privada } \\
\text { Dinheiro }\end{array}$ \\
\hline
\end{tabular}

Fonte: Elaborado por João Antônio de Paula, a partir dos trabalhos de Veblen (1965 e 1967).

Carl Schorske e outros já mostraram o rico entrelaçamento cultural que a cultura austro-vienense do fin-de-siécle experimentou. Mahler, Schönberg e Berg, na música; Kokoschka, Münch e Klimt, na pintura; Schnitzler, Musil e Kafka, na literatura; Mach, Wittgenstein e Popper, na filosofia; Freud, na psicanálise; e Boltzmann, na física, são filhos espirituais de uma cidade, de uma civilização, de uma época crepuscular (Schorske, 1988).

O quanto o esgotamento agônico do império austro-húngaro, naquele pré1914, terá determinado essa múltipla e complexa irrupção, que em sua diversidade guarda uma unidade significativa? Não é possível estabelecer isso ao certo. Contudo, não estará em erro quem reconhecer nestas variadas tendências e obras um traço comum: o abandono das certezas, a sensação de esgarçamento das formas tradicionais de representação, a valorização da subjetividade, a descoberta do inconsciente, do quanto somos movidos por motivações e projetos ocultos e infensos à racionalidade estrita... A música de Mahler e seu cromatismo que, distendido, anuncia o atonalismo; o expressionismo de Kokoschka e Münch e o ultra-decorativismo de Klimt, que prenunciam a explosão da figuração; a literatura de extremismos das obras de Schnitzler, Musil e Kafka, que são o registro de um novo inferno, feito de vastas e asfixiantes burocracias, da vitória do esvaziamento do sentido da vida; o neopositivismo filosófico e seus impasses, de que resultarão tanto o mergulho 
místico de Wittgenstein quanto o relativismo de Popper; a física probabilística de Boltzmann, a melhor tradução dos limites do determinismo da física clássica; a psicanálise de Freud, a explicitação dos limites da auto-consciência racionalista.

Nesse passo, pode ser que alguém se lembre da escola neoclássica austríaca, que é contemporânea dos movimentos considerados aqui e, com esta lembrança, problematize a questão. Afinal, se a Viena "finisecular" pareceu assumir a ambigüidade e o cromatismo, os ritmos cambiantes, também foi reduto de vocação neopositivista em filosofia e neoclássica em economia. Contudo, em que pesem as fortes e decisivas similitudes entre as três versões pioneiras do neoclassicismo, é importante reconhecer as singularidades da contribuição de Menger e dos seus sucessores Von Wieser, Böhm-Bawerck, Von Mises e Hayek.

Em que pesem diferenças de nuances, entre suas várias gerações, a escola austríaca se caracterizará pela radical centralidade que atribuirá à subjetividade na construção de sua teoria do valor, que será a base, por derivação, de sua teoria da produção. É ainda esta atribuição de centralidade à subjetividade que está na base de outra contribuição austríaca ao pensamento neoclássico - o individualismo metodológico. Hayek viu assim a questão e acentuou, sobre isso, a importância da obra de Menger de 1883, Problemas de Economia e Sociologia - obra que foi, em certos aspectos, "tão importante para o desenvolvimento da escola austríaca como sua obra anterior, os Grunsätze, ainda que os detalhes de suas opiniões metodológicas não fossem plenamente aceitos nem mesmo em sua própria escola. Porém, a justificativa sistemática do que posteriormente foi chamado por Schumpeter (1908) de "individualismo metodológico" e a análise da evolução das instituições sociais (no que ressuscitou idéias originalmente propostas por Bernard Mandeville e David Hume) exerceram uma influência profunda em todos os membros da escola e, mais adiante, muito além dos limites da escola (Hayek, 1975, v. 7, p. 754).

$\mathrm{O}$ que se quer sublinhar aqui é que, se o individualismo metodológico se incorporou à tradição neoclássica, como um de seus fundamentos, é discutível, no mínimo, a sua plena compatibilidade com o outro e decisivo fundamento do pensamento neoclássico, que é a teoria do equilíbrio geral. Na verdade, talvez seja o caso de reconhecer que as três obras pioneiras da chamada revolução marginalista, as obras de Jevons, Menger e Walras, vão possibilitar três caminhos que, confluentes, em alguma medida, resultarão, de fato, em perspectivas diferenciadas. No caso de Jevons, via tradição marshalliana, assistiu-se à instauração de uma perspectiva que se abriu tanto para a economia do bem-estar, de Pigou, quanto, na década de 1920/1930, para formas de 
questionamento do equilíbrio dos mercados com Sraffa, Chamberlain, Joan Robison e Keynes. No caso de Walras, e seus desdobramentos contemporâneos, tem-se o dominante e ortodoxo dos programas neoclássicos de pesquisa. Em sua versão austríaca, a tradição neoclássica desdobrar-se-á, com Hayek, em uma postura que, sendo conservadora, o é de maneira alternativa ao decorrente da tradição walrasiana, posto que partindo não da suposição da existência de um equilíbrio natural e exaustivo, mas da possibilidade da ordem a partir de uma situação inicial de absoluta desorganização. Nesse sentido, Hayek e sua teoria da "ordem social espontânea" têm paralelos com epistemologias contemporâneas decisivas, como os "sistemas autopoiéticos", de Maturana e Varela, e as "estruturas dissipativas", de Prigogine (Dupuy, 1997, v. I, p. 260).

Assim, vejam-se as relações entre pensamento filosófico, literatura e pensamento econômico como marcadamente complexas e abertas, distantes de quaisquer reducionismos.

É o que se quer denotar com o quadro a seguir:

\begin{tabular}{|c|c|c|c|}
\hline Período & Pensamento filosófico & Correntes literárias & Pensamento econômico \\
\hline 1776 & Racionalismo & Classicismo & Economia política clássica \\
1817 & Empirismo & & \\
\hline 1843 & Romantismo & Romantismo & Escola histórica alemã \\
1883 & Historismo & & \\
\hline 1803 & Utilitarismo & Realismo & $\begin{array}{c}\text { Economia neoclássica } \\
\text { marginalista }\end{array}$ \\
1874 & Positivismo & Naturalismo & Institucionalismo \\
\hline 1899 & Pragmatismo & Naturalismo & \\
1914 & Evolucionismo & Simbolismo & \\
\hline
\end{tabular}

Fonte: Elaborado por João Antônio de Paula.

Trata-se, do ponto de vista simbólico, de reconhecer os vínculos, a atração irresistível entre certas tendências da manifestação do espírito, entre certas concepções de mundo e suas determinações histórico-materiais. Assim, o mundo que supera as restrições e particularismos feudais tem que se afirmar pela instauração de um universalismo que, sendo absoluto, tem de dar conta e ser referência de tudo. É esta a função da filosofia cartesiana, do paradigma newtoniano, que tanto incidirão sobre a economia, com Smith, quanto sobre a filosofia, com Kant. Mas é também este mesmo universalismo racionalista que está na base de uma tradição literária que vai de Racine a Flaubert: 
As peças de Ibsen e os romances de Flaubert são as obras-primas desse segundo período do classicismo moderno, como o foram, no primeiro, as obras de Racine e Swift. A arte de Flaubert e Ibsen é novamente, como a arte dos escritores do século XVII, escrupulosamente impessoal, é objetiva e insiste na precisão da linguagem e na economia da forma. (Wilson, 1967, p. 14).

Essa descrição da forma da literatura do Classicismo não está longe de descrever os procedimentos e propósitos de uma teoria como a do economista David Ricardo, nem da pretensão formal do economista Walras.

Contudo, é quase um outro universo espiritual o que emergirá com o pensamento institucionalista, em economia, e, mais desconcertante, com a escola neoclássica austríaca. É que essas correntes, diferentes em propósitos ideológicos, são reverberações de uma outra afinidade eletiva, são capítulos do movimento geral do Simbolismo, o qual, ao contrário do imantado pelo Classicismo-Realismo-Naturalismo, é o reino das sensações, das percepções cambiantes, dos cromatismos de sons e cores... Diz Wilson:

Insinuar coisas, em vez de formulá-las ostensivamente, era, dessarte, um dos principais objetivos do simbolismo. (...) Toda percepção ou sensação que tenhamos, a cada momento de consciência, é diferente de todas as outras; por conseguinte, torna-se impossível, comunicar nossas sensações, conforme as experimentamos efetivamente, por meio da linguagem convencional e universal da literatura comum. (...) o que é tão especial, tão fugidio e tão vago não pode ser expresso por exposição ou descrição direta, mas somente através de uma sucessão de palavras, de imagens que servirão para sugeri-lo ao leitor. (Wilson, 1967, p. 22).

Se este é o universo de Valéry, de Proust, de Joyce, é também o de Commons, de Ely, é também o de Veblen, de Mitchell, teóricos centrais do institucionalismo em seus primeiros tempos.

Mitchell declarou que "a economia é necessariamente uma das ciências do comportamento humano, (...) e só pode ser entendida por um estudo genético das instituições e do comportamento econômico"; ele que quer substituir o método "dedutivo mecanicista" dos clássicos por um método experimental estatístico, juntamente com a cooperação com outras ciências sociais (Normano, 1945, p. 195).

É também como denúncia do pretenso universalismo da economia clássicaneoclássica que vai se manifestar a escola histórica alemã. Nesse sentido, há claras e fortes ressonâncias do historicismo alemão sobre o institucionalismo norte-americano. (Surányi-Unger, 1975, v. 7, p. 750).

Mas se o pensamento institucionalista é a denúncia de uma vitória - a do grande capital predatório norte-americano - a escola histórica alemã é o apelo a um esforço de superação de atraso relativo, com base na mobilização da forte tradição estatista alemã. Diz Parsons: 
É sem dúvida significativo que a economia clássica nunca tenha se arraigado realmente nas universidades alemãs, posto que não havendo sido nunca apenas uma disciplina técnica senão uma ideologia, expressava um ideal de independência da "empresa" frente ao Estado e outros interesses "sociais", tudo o que não tem afinidade com a mentalidade alemã. (Parsons, 1967, p. 97, grifo meu).

Para os alemães, mais uma vez, a estratégia de superação de seu atraso relativo repousou na busca de matrizes alternativas às dos países mais avançados. No campo dos estudos literários-artísticos, a estratégia alemã, no final do século XVIII, para se contrapor à hegemonia francesa, ao monopólio de proximidade com a tradição clássica, que a França reivindicava pelo cultivo da cultura romano-latina, baseou-se no retorno à matriz grega, a qual é a base da cultura romano-latina. Nesse sentido, a estratégia alemã é de um recuo que permite ultrapassagem, na medida em que a tradição grega é mais ampla e avançada que a latina, permitindo uma releitura, que autoriza a reivindicação da superioridade da apropriação alemã da cultura clássica e seus rebatimentos modernos.

É assim que os alemães com Hölderlin, Nietzsche, Heidegger, entre outros nomes significativos, vão se colocar como os grandes mestres da cultura clássica e, desse modo, mestres da cultura ocidental.

No campo do pensamento econômico, a estratégia alemã segue o essencial do movimento descrito, que é a recusa da tradição hegemônica, e a busca da sua ultrapassagem pela reivindicação de um outro paradigma. No caso, aqui, em oposição à tradição do racionalismo universalizante franco-britânico, os alemães lançarão o Romantismo nacionalista de Herder-Fichte, o Volksgeist, que inspirará a economia protecionista de Friedrich List, base da escola histórica alemã em suas diversas gerações.

\section{Referências}

CANSINOS ASSENS, Rafael. Introducción a Obras Completas de Johann W. Goethe. 5. ed. Trad. esp. Madrid: Aguilar, 1968. t. II.

CARPEAUX, Otto Maria. História da Literatura Ocidental. Rio de Janeiro: O Cruzeiro, 1962. v. IV.

COHN, Gabriel. Crítica e resignação. São Paulo: T. A. Queiroz, 1979.

DOBB, Maurice. Teoria del Valor y de la Distribución desde Adam Smith. Trad. esp. Buenos Aires: Siglo XXI, 1975.

DUPUY, Jean-Pierre. L'autonomie du Social. De la contribution de le Pensée Systémique à la theorie de la société. In: JACOB, André (Org.). L'Univers Philosophique. Paris: PUF, 1997. v. I.

FOUCAULT, Michel. As palavras e as coisas. Trad. port. Lisboa: Portugália, [s.d.]. 
GABEL, Joseph. Sociologia de la Alienación. Trad. esp. Buenos Aires: A. Monurtu, 1973. p. 173-188.

GERSCHENKRON, Alexander. El atraso económico en su perspectiva histórica. Trad. esp. Barcelona: Ariel, 1968.

HAYEK, Friedrich A. von. La Escuela Austríaca. In: SILLS, Davi L. (Org.). Enciclopédia Internacional de las Ciencias Sociales. Trad. esp. Madrid: Aguilar, 1975. v. 7. KOYRÉ, Alexander. Do mundo fechado ao universo infinito. Trad. port. Rio de Janeiro: Forense-Universitária/USP, 1979.

LALANDE, André. Vocabulário técnico y crítico de la Filosofia. Trad. esp. Buenos Aires: El Ateneo, 1953. v. I

LÖWY, Michael. Redenção e utopia. Trad. port. São Paulo: Cia. Das Letras, 1989.

MANDEL, Ernest. A formação do pensamento econômico de Karl Marx. Trad. port. Rio de Janeiro: Zahar, 1968.

MARX, Karl. Teoria sobre la Plusvalia. In: . Obras fundamentales. Trad. esp.

México: FCE, 1980. t. III, v. 14.

NORMANO, J. F. As idéias econômicas na América do Norte. Trad. port. São Paulo: Atlas, 1945.

PARSONS, Talcott. Ensayos de Teoria Sociológica. Trad. esp. Buenos Aires: Paidós, 1967.

PAULA, João Antônio de. Walras no Journal des Économistes: 1860-65. Revista Brasileira de Economia, v. 56, n. 1, jan./março, 2002.

ROLL, Eric. História das doutrinas econômicas. 3. ed. Trad. port. São Paulo: Cia Editora Nacional, 1972.

RUBIN, Isaak I. Ensayos sobre la Teoria Marxista del Valor. Trad. esp. Buenos Aires: Siglo XXI, 1974.

SCHORSKE, Carl E. Viena Fin-de-Siécle. Trad. port. São Paulo: Cia. das Letras, 1988. SCREPANTI, Ernesto; ZAMAGNI, Stefano. An Outline of the History of Economic Thought. Trad. inglesa. Oxford: Clarendon Press, 1993.

SURÁNYI-UNGER, Theo. La Escuela Histórica. In: SILLS, Davi L. (Org.). Enciclopédia Internacional de las Ciencias Sociales. Trad. esp. Madrid: Aguilar, 1975. v. 7 .

VEBLEN, Thorstein. A teoria da classe ociosa. Trad. port. São Paulo: Pioneira, 1965. . A teoria da empresa industrial. Trad. port. Porto Alegre: Globo, 1967.

WEBER, Max. Ensayos sobre Sociologia de la Religión. 2. ed. Trad. esp. Madrid: Taurus, 1992. v. I.

WILSON, Edmund. O Castelo de Axel. Trad. port. São Paulo: Cultrix, 1967. 